\title{
METHODS FOR SELECTING THE BEST PARTNER CONSTRUCTION ENTERPRISE IN TERMS OF PARTNERING RELATIONS
}

\author{
Elżbieta Radziszewska-Zielina \\ Department of Civil Engineering, Cracow University of Technology, \\ Warszawska 24, 31-155 Cracow, Poland \\ E-mail: eradzisz@izwbit.wil.pk.edu.pl
}

Received 29 Dec. 2009; accepted 22 June 2010

\begin{abstract}
The author proposes fourteen parameters for assessing partnering relations in construction enterprises. By means of these parameters, experts in construction enterprises apply a five-point scale in order to evaluate enterprise relations with four transactors within its microenvironment. The parameters describing relationships are adopted as assessment criteria. The question of selecting the best construction enterprise for cooperation is a multi-criteria issue. The author's solution is based on the ELECTRE III method and elaborates two alternative methods of selecting the best construction enterprise on the basis of the analysis of partnering relations between construction enterprises being studied and their transactors within the microenvironment and indicates one of the above introduced methods as preference. Two methods have been developed with a view to supporting a decision-making system in a construction enterprise as regards the choice of a subcontractor. Relevant calculations can be made by the enterprise decision-maker using the ConRel programme elaborated by the Cracow University of Technology.
\end{abstract}

Keywords: construction enterprise, partnering, partnering relations, subcontractor selection, multi-criteria method, ELECTRE III.

\section{Introduction}

Partnering is "a long-term commitment between two or more organizations for the purposes of achieving specific business objectives by maximizing the effectiveness of resources considering each participant. This requires changing traditional relationships to a shared culture without regard to organizational boundaries. The relationship is based on trust, dedication to common goals and understanding each other's individual expectations and values" (CII 1991). Partnering is "a way of achieving an optimum relationship between a customer and a supplier" (AGC 1991).

Crucial work describing the seven pillars of partnering in the construction industry is a book by Bennett and Jayes (1998) frequently referred to by other authors. A system of assessing partnering cooperation is proposed by e.g. Cheung et al. (2003a), Bayliss et al. (2004), Nyström (2008) and Cheng and Li (2004). Beach et al. (2005) assess progress made by the British construction industry in the implementation of the partnering approach and predict the further development thereof. Another analysis of the partnering approach in the British construction industry is offered by Black et al. (2000). Significantly, there is a large number of analyses conducted by the Far East markets, e.g. (Phua and Rowlinson 2004; Kwan and Ofori 2001). Koraltan and Dikbas (2002) describe the aspect which affects partnering in the Turkish construction industry. $\mathrm{Ng}$ et al. (2002), Glagola and
Sheedy (2002) examine the development of partnering in construction projects commissioned by the government of Australia. Among theoretical works, some regard trust as the most important factor of successful partnering, e.g. (Cheung et al. 2003b; Cheung 2007; Kumaraswamy et al. 2005). The analyses making the use of the game theory and "the prisoner's dilemma" are, for example, Sacks and Harel (2006) and Wong et al. (2005). Another approach is the application of social network analysis by Pryke (2004). Information exchange between an enterprise and its environment is described in works by Drejer and Vinding (2006), Chan et al. (2005) and Lipshitz et al. (2002). Although partnering as a strategy in the construction industry is relatively new, its concept has already spread over very different and often very distant parts of the world. Most studies appear in the USA, Great Britain, Australia and Hong Kong. Because this is a new approach and a particular novelty in the construction industry where competition is deeply rooted as noted by numerous authors, the enterprises that implement partnering encounter the whole range of problems. It is no wonder then that apart from optimistic works that promote project as well as strategic partnering and describe the advantages of this approach, there are a number of studies pointing out to various problems both internal (concerning the participants of the project) and external (e.g. legal) which partnering enterprises have to face. These problems have been described in works by Bresnen and Marshall (2000) and Kululanga et al. (2001). However, 
none of them claims that partnering is an unsuitable approach in the construction industry or that the trend towards employing it in this industry will soon be over as it seems to be just the opposite.

The papers on the subject produced by the author herself should also be mentioned. A full review of the models in which partnering plays a key part as well as her model of partnering relations in the construction industry is presented in (Radziszewska-Zielina 2008c). The barriers to creating partnering relations on the part of Polish construction enterprises as well as the advantages of using the partnering approach in the industry are described in (Radziszewska-Zielina 2008b). The author demonstrates the characteristics of activity provided by the construction enterprise on the market in (RadziszewskaZielina 2008a). Her research into Polish, Slovak and Ukrainian construction enterprise partnering relationships is presented in (Radziszewska-Zielina 2010b). She also analyses the influence that the level of partnering relations has on the selected indexes of success using an example of Polish construction enterprises in (Radziszewska-Zielina 2010a).

There are many articles on the models and methods of selecting a contractor. For example, (Zavadskas et al. 2008) present contractor assessment and selection on the basis of multi-attribute methods in a competitive and risky environment. The assessment and choice of the most suitable contractor for a project is an important element of the project management cycle. A paper by Turskis (2008) applies ordering feasible solution alternatives in terms of a preferability technique in order to introduce the multi-attribute contractor ranking method. Ulubeyli et al. (2010) describe the methods of subcontractor selection used by Turkish contractors in international projects. Although the current aspects of subcontractor and contractor selection are analysed in many other publications, e.g. (Plebankiewicz 2010), these studies are conducted mostly from the investor's perspective rather than from that of the construction enterprise and are not carried out in the context of building partnering relations unlike the author's work.

The present paper elaborates a method of selecting the best construction enterprises for partnering cooperation on the basis of the analysis of partnering relations between construction enterprises with transactors in their microenvironment. The purpose of the software commissioned is to support an enterprise decision-making system as regards the choice of a subcontractor, i.e. another construction enterprise for partnering cooperation.

Kapliński (2008) notes computer-based methods used by construction enterprises in the decision-making process. The techniques of planning and decision-making are developing but, at the same time, are still insufficiently used by Polish enterprises. In another paper (Kapliński 2009), in regard of Polish construction enterprises and application of various IT systems which aid information flow and facilitate an enterprise cooperation with its environment, the author notes the dynamic development of IT tools used for enterprise and project management. $\mathrm{He}$ states that the experience of construction enterprises shows that in order to function well, they have to integrate their management systems into the environment. This goal is achieved via such measures as cooperation with suppliers, subcontractors and investors. Kapliński et al. (2002) point to the relationship between a construction enterprise and the microenvironment as one of the three basic research topics related to the organization and management of construction enterprises.

The ELECTRE method is relatively rarely applied in the field of civil engineering; however, there are several interesting works on the subject. ELECTRE I was first applied in 1985. Two years later, this research was summarised by Zavadskas in two publications (Zavadskas 1987a, 1987b). The application of the ELECTRE III method is described in the articles by Azar et al. (2001) who propose the optimization of the building envelope during the architectural sketch design stage using multiple construction actors of the Multiple Criteria Decision Aid; Cavallo and Norese (2001) carried out the evaluation and mapping of erosion and landslide risk using GIS and Multicriteria Analysis; Thiel and Mróz (2001) applied the Multi-Criterion Decision Aid Method for designing heating systems in museums; Tam et al. (2003) use the ELECTRE III method to evaluate the performance of construction plants in their case study on concrete vibrators; Zavadskas et al. (2004) conduct a multicriteria evaluation of commercial construction projects for the purposes of investment. In more recent works, Mróz and Thiel (2005) apply multiple criteria decision analysis in order to evaluate a heating system in buildings; Thiel (2006) attempts to define participant preferences in a decision-aiding process where the participant is a collective body; in another work, Thiel (2008) describes the relative importance of criteria in the case when the number of decision-makers is the so-called small sample. One of the latest works on the subject is done by Ulubeyli and Kazaz (2009) who present a multiple criteria decision-making approach in terms of concrete pump selection. The ELECTRE IV method was applied by such researchers as Ustinovichius et al. (2006) who assessed investment projects for the revitalization of rural areas by means of the Multiple Criteria Analysis. However, the author of this paper has not encountered any application of the ELECTRE method to partnering cooperation.

\section{The Algorithm of Selecting Construction Enterprises for Partnering Cooperation Applying the ELECTRE III Method}

The author proposes fourteen parameters for assessing partnering relations of construction enterprises. It is proposed that by means of these parameters, the experts of the construction enterprise should assess relations between their enterprise and four transactors in accordance with a five-point scale. The fourteen parameters determining relations are adopted as assessment criteria. The question of selecting the best construction enterprise for cooperation is a multi-criteria issue and a discrete problem of multiple criteria decision-making. In order to solve 
this problem, the author decided to make the use of the ELECTRE III method.

There is no commercial software on the market which uses the ELECTRE method. Commercial versions of the programmes referred to by various authors have not been produced as they are designed to aid individual research of these authors, e.g. EL1Sv3.0 programme (Trzaskalik 2006) based on the ELECTRE I method algorithm. These programmes cannot be applied in order to solve the presented problem owing to the specific form of threshold functions. On the basis of the data contained in the questionnaires on relation diagnosis filled in by the experts employed in construction enterprises being studied, the author has determined that weight-importance coefficients (in our case, the weights of particular relation parameters) important for the correct functioning of the ELECTRE method constitute the means. The existing programmes require setting weight-importance coefficients that will be similar to all variants (in our case, for all construction enterprises). Due to difficulties in adapting the existing software to the expected requirements in our case, it consequently became necessary to elaborate a new programme.

Considering a multiple criteria task, a significant question is how to aggregate assessments in relation to particular criteria in order to model decision maker's preferences. In light of the ELECTRE III method, decision maker's preferences are modelled on the basis of indifference relations, weak preference and strong preference. These relations are defined by setting the threshold functions of indifference and preference as well as by weight-importance coefficients. Roy (1990) adopted an approach and made an assumption that strong dominance of variant $a^{i}$ over variant $a^{j}$ in relation to one of the criteria resulted in the rejection of the hypothesis regarding the dominance of variant $a^{j}$ over variant $a^{i}$ even if variant $a^{j}$ was strongly preferred with regard to the remaining criteria. Decision maker's preference for this type of situation is determined by means of $v_{k}$ veto threshold function.

A comparison of two decision making variants with regard to the $k$ th criterion may reveal one of three basic situations, namely, indifference, weak preference and strong preference (Fig. 1). The definitions of these situations are as follows:

Variant $a^{j}$ is the relation between indifference $I_{k}$ and variant $a^{i}$ if

$$
a^{j} I_{k} a^{i} \Leftrightarrow f_{k}\left(a^{j}\right)-f_{k}\left(a^{i}\right) \leq q_{k}\left(f_{k}\left(a^{i}\right)\right) .
$$

Variant $a^{j}$ is the relation between weak preference $Q_{k}$ and variant $a^{i}$ if

$$
a^{j} Q_{k} a^{i} \Leftrightarrow q_{k}\left(f_{k}\left(a^{i}\right)\right)<f_{k}\left(a^{j}\right)-f_{k}\left(a^{i}\right) \leq p_{k}\left(f_{k}\left(a^{i}\right)\right) .
$$

Variant $a^{j}$ is the relation between strong preference $P_{k}$ and variant $a^{i}$ if

$$
a^{j} P_{k} a^{i} \Leftrightarrow p_{k}\left(f_{k}\left(a^{i}\right)\right)<f_{k}\left(a^{j}\right)-f_{k}\left(a^{i}\right),
$$

where $q_{k}\left(f_{k}(a)\right)$ - the threshold function of indifference, $p_{k}\left(f_{k}(a)\right)$ - the threshold relation of preference, $f_{k}(a)$-variant assessment criterion, $k=1, \ldots, n$.

Incomparability occurs when the ith solution is better than the $j t h$ solution in respect of one criterion while in respect of another criterion, the ith solution is worse than the $j$ th solution. The application of ELECTRE methods allows removing some incomparable cases by modelling decision maker's preferences.

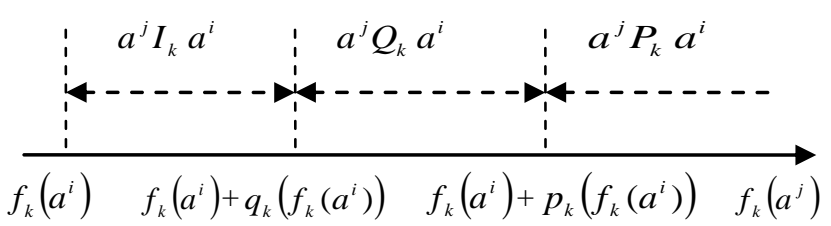

Fig. 1. A graphic representation of the borders of indifference zones, weak preference and strong preference when $f_{k}\left(a^{j}\right) \geq f_{k}\left(a^{i}\right)$

$$
\text { Source: Roy } 1990
$$

Roy (1990) defines the following five collective situations:

- lack of preference - groups the situations of indifference and incomparability without the possibility of distinguishing between them,

- preference in a broad sense - groups the situations of weak and strong preference without the possibility of distinguishing between them,

- supposition of preference - groups the situations of weak preference and indifference without the possibility of distinguishing between them,

- K - preference - groups the situations of strong preference and incomparability without the possibility of distinguishing between them,

- outranking - groups the situations of weak and strong preference and indifference without the possibility of distinguishing between them.

The indifference threshold connected with criterion $f_{k}$ is constituted by function $q_{k}\left(f_{k}(a)\right)$

$$
\begin{gathered}
\forall a^{i}, a^{j} \in A \\
0 \leq f_{k}\left(a^{j}\right)-f_{k}\left(a^{i}\right) \leq q_{k}\left(f_{k}\left(a^{i}\right)\right) \Rightarrow \\
\Rightarrow a^{j} I_{k} a^{i} \wedge f_{k}\left(a^{j}\right)-f_{k}\left(a^{i}\right)>q_{k}\left(f_{k}\left(a^{i}\right)\right) \Rightarrow a^{j} L_{k} a^{i},
\end{gathered}
$$

where $I_{k}$ - relation between indifference and criterion $f_{k}, L_{k}$ - relation between preference in a broad sense and criterion $f_{k}$.

The preference threshold related to criterion $f_{k}$ is constituted by function $p_{k}\left(f_{k}(a)\right)$

$$
\forall a^{i}, a^{j} \in A
$$

$$
\begin{aligned}
& f_{k}\left(a^{j}\right)-f_{k}\left(a^{i}\right)>p_{k}\left(f_{k}\left(a^{i}\right)\right) \Rightarrow \\
& \Rightarrow a^{j} P_{k} a^{i} \wedge 0 \leq f_{k}\left(a^{j}\right)-f_{k}\left(a^{i}\right) \leq p_{k}\left(f_{k}\left(a^{i}\right)\right) \Rightarrow a^{j} J_{k} a^{i},
\end{aligned}
$$


where $P_{k}$ - relation between strong preference and criterion $f_{k}, J_{k}$ - relation between the supposition of preference and criterion $f_{k}$.

Criterion $f_{k}$ along with the threshold functions of equivalence and preference is called the pseudo-criterion. The following condition is fulfilled by

$$
\begin{aligned}
& f_{k}\left(a^{j}\right) \geq f_{k}\left(a^{i}\right) \Rightarrow \\
& \Rightarrow\left\{\begin{array}{ccc}
a^{j} I_{k} a^{i} & \text { for } & f_{k}\left(a^{j}\right)-f_{k}\left(a^{i}\right) \leq q_{k}\left(f_{k}\left(a^{i}\right)\right) \\
a^{j} Q_{k} a^{i} & \text { for } & \left.q_{k}\left(f_{k}\left(a^{i}\right)\right)<f_{k}\left(a^{j}\right)-f_{k}\left(a^{i}\right) \leq p_{k}\left(f_{k}\left(a^{i}\right)\right)\right\} . \\
a^{j} P_{k} a^{i} & \text { for } & p_{k}\left(f_{k}\left(a^{i}\right)\right)<f_{k}\left(a^{j}\right)-f_{k}\left(a^{i}\right)
\end{array}\right\}
\end{aligned}
$$

The description of the ELECTRE III method (the way of calculating the values of concordance and credibility coefficients for each pair of decision variants, the procedure of the descending and ascending distillation) may be found in literature on the subject, e.g. Trzaskalik (2006) after Roy and Bouyssou (1993), and therefore for that reason, is not described in our case. The orders obtained as a result of distillation procedures are used to determine the final collective ranking. In order to interpret distillation results, the following rules are used:

- variant $a^{i}$ is regarded as better than variant $a^{j}$ if, in at least one of the orders, $a^{i}$ is placed higher than $a^{j}$ while in the second order, it is at the same level;

- variant $a^{j}$ is regarded as better than variant $a^{i}$ if, in at least one of the orders, $a^{j}$ is placed higher than $a^{i}$ while at the second order, it is at the same level;

- variants $a^{i}$ and $a^{j}$ are regarded as equivalents if, in both cases, $a^{i}$ and $a^{j}$ are located at the same level;

- variants $a^{i}$ and $a^{j}$ are regarded as incomparable if, in one of the orders, $a^{i}$ is placed higher and in another lower than $a^{j}$.

The algorithm of the ELECTRE III method was used to elaborate the method of selecting a construction enterprise for partnering cooperation. Fourteen criteria $f_{k}$ were adopted, where $k \in\{1,2,3, \ldots \ldots 14\}$ (Table 1), in relation to which, decision variants (construction enterprises) are assessed.

The author has assumed that relations with a construction enterprise can range on a five-point scale, i.e. from 1 - traditional relations to 5 - partnering relations. Table 1 gives a qualitative presentation of two extremes of the scale. Thus, the criteria are constituted by the particular parameters of relations which assume the values in the range of $x \in\{1,2,3,4,5\}$.

With the help of experts from construction enterprises, the author analysed the significance of particular points on the scale (assessments) for particular relation parameters (criteria) in order to define the threshold functions of indifference, strong preference and veto which were then used to model the preferences of the enterprise decision maker (the one to choose a subcontractor).
Table 1. The adopted symbol and name of a relation parameter (criterion) and its characteristics regarding the tradi-

\begin{tabular}{|c|c|c|}
\hline Criterion & $\begin{array}{c}\text { Traditional } \\
\text { relations }\end{array}$ & Partnership relations \\
\hline $\begin{array}{l}f_{1} \\
\text { The basis of } \\
\text { ordering }\end{array}$ & $\begin{array}{l}\text { Choice based on } \\
\text { the lowest price }\end{array}$ & $\begin{array}{l}\text { Price is not the most } \\
\text { important issue. A ho- } \\
\text { listic approach and the } \\
\text { choice of partner based } \\
\text { on, among others, the } \\
\text { high quality of partner's } \\
\text { services and relations, } \\
\text { problem-solving ability, } \\
\text { credibility, loyalty and a } \\
\text { positive image }\end{array}$ \\
\hline $\begin{array}{l}f_{2} \\
\text { The number } \\
\text { of suppliers }\end{array}$ & $\begin{array}{l}\text { Large suppliers } \\
\text { compete with one } \\
\text { another }\end{array}$ & $\begin{array}{l}\text { Limited to the best } \\
\text { partners }\end{array}$ \\
\hline $\begin{array}{l}f_{3} \text { An ap- } \\
\text { proach to } \\
\text { service quali- } \\
\text { ty control }\end{array}$ & $\begin{array}{l}\text { The buyer performs } \\
\text { inspection every } \\
\text { time when goods } \\
\text { are received }\end{array}$ & $\begin{array}{l}\text { Quality control is per- } \\
\text { formed by the supplier. } \\
\text { The buyer trusts a prov- } \\
\text { en partner }\end{array}$ \\
\hline $\begin{array}{l}f_{4} \\
\text { The division } \\
\text { of costs }\end{array}$ & $\begin{array}{l}\text { Savings in costs are } \\
\text { absorbed by the } \\
\text { buyer, so the sup- } \\
\text { plier hides them. A } \\
\text { win-lose strategy }\end{array}$ & $\begin{array}{l}\text { A precise definition of } \\
\text { the share in the costs, } \\
\text { profit and risk related to } \\
\text { contract execution. A } \\
\text { win-win strategy }\end{array}$ \\
\hline $\begin{array}{l}f_{5} \\
\text { Adaptation } \\
\text { to market } \\
\text { changes }\end{array}$ & $\begin{array}{l}\text { It is the buyer who } \\
\text { determines the } \\
\text { response to chang- } \\
\text { ing market condi- } \\
\text { tions }\end{array}$ & $\begin{array}{l}\text { The buyer and supplier } \\
\text { plan their actions and } \\
\text { elaborate their plan of } \\
\text { adaptation to market } \\
\text { changes together }\end{array}$ \\
\hline $\begin{array}{l}f_{6} \\
\text { Participation } \\
\text { in the new } \\
\text { offer of the } \\
\text { enterprise }\end{array}$ & None & $\begin{array}{l}\text { An active, common } \\
\text { effort towards the con- } \\
\text { stant improvement of } \\
\text { services }\end{array}$ \\
\hline $\begin{array}{l}f_{7} \\
\text { Mutual } \\
\text { relations }\end{array}$ & $\begin{array}{l}\text { Purely formal, } \\
\text { commercial and } \\
\text { based on contracts }\end{array}$ & $\begin{array}{l}\text { Often informal, based } \\
\text { on trust. Cooperation } \\
\text { between partners }\end{array}$ \\
\hline $\begin{array}{l}f_{8} \\
\text { The method } \\
\text { of commu- } \\
\text { nication }\end{array}$ & $\begin{array}{l}\text { Minimal, limited } \\
\text { to orders and } \\
\text { complaints }\end{array}$ & $\begin{array}{l}\text { Open, frequent, initiated } \\
\text { by both parties }\end{array}$ \\
\hline $\begin{array}{l}f_{9} \\
\text { Information } \\
\text { sharing }\end{array}$ & $\begin{array}{l}\text { Limited infor- } \\
\text { mation flow }\end{array}$ & $\begin{array}{l}\text { Information exchange. } \\
\text { An open, quick infor- } \\
\text { mation flow }\end{array}$ \\
\hline $\begin{array}{l}f_{10} \\
\text { Conflict } \\
\text { solving }\end{array}$ & $\begin{array}{l}\text { It is the buyer } \\
\text { alone who solves } \\
\text { conflicts }\end{array}$ & $\begin{array}{l}\text { Conflicts are solved } \\
\text { together. A mechanism } \\
\text { for conflict solving exists }\end{array}$ \\
\hline $\begin{array}{l}f_{11} \\
\text { Standards, } \\
\text { rules of } \\
\text { behaviour }\end{array}$ & $\begin{array}{l}\text { No common rules. } \\
\text { Different aims. } \\
\text { Lack of flexibility }\end{array}$ & $\begin{array}{l}\text { Common values and } \\
\text { aims. The partners are } \\
\text { flexible concerning pro- } \\
\text { cedures, standards and } \\
\text { habits }\end{array}$ \\
\hline $\begin{array}{l}f_{12} \\
\text { Frequency } \\
\text { of contact }\end{array}$ & One-off contacts & $\begin{array}{l}\text { Frequent, permanent } \\
\text { contacts and permanent } \\
\text { relations }\end{array}$ \\
\hline $\begin{array}{l}f_{13} \\
\text { An approach } \\
\text { to the issues } \\
\text { concerning } \\
\text { quality }\end{array}$ & $\begin{array}{l}\text { The focus is ex- } \\
\text { clusively on the } \\
\text { technical quality } \\
\text { of a product }\end{array}$ & $\begin{array}{l}\text { A complex approach to } \\
\text { quality issues. The } \\
\text { quality of relations is } \\
\text { important }\end{array}$ \\
\hline $\begin{array}{l}f_{14} \\
\text { Trust }\end{array}$ & $\begin{array}{l}\text { Lack of trust in } \\
\text { business }\end{array}$ & Visible trust \\
\hline
\end{tabular}
tional approach and partnering approach 
In the method proposed by the author, the weights and assessments of particular criteria are fed into electronic questionnaires (relationship diagnostic questionnaire) on the basis of their own observations made by the experts from construction enterprises regarded as candidates for partnering cooperation. If a decision-maker who chooses a subcontractor suitable for partnering cooperation has appropriate knowledge, s/he can provide data.

The threshold functions of indifference for criteria are defined as follows:

$q_{k}(x)=\left\{\begin{array}{ccc}0 & \text { for } & x=1 \\ 1 & \text { for } & x \in\{2,3,4,5\}\end{array}\right\}$ for criteria $f_{k}$,

where $k \in\{1,8,9,13\}$,

$q_{k}(x)=1$ for criteria $f_{k}$, where $k \in\{2,4\}$,

$q_{k}(x)=0$ for criteria $f_{k}$, where $k \in\{3,5,6,7,10,11,12,14\}$.

For criteria $f_{1}, f_{8}, f_{9}, f_{13}$, assessment 1 differs significantly from assessment 2 ; for this reason, the assumed threshold value is 0 . This means that assessments 1 and 2 are not equivalent. For the remaining assessment values, the assumed threshold value equals 1 . This means that assessments which vary by value 1 are considered equivalent.

It was assumed for criteria $f_{2}, f_{4}$ that assessments varying in value 1 were considered equivalent.

For the remaining criteria, it was assumed that two assessments were equivalent only if they were equal. The threshold functions of strong preference for the criteria are defined as follows:

$$
p_{k}(x)=3 \text { for criteria } f_{k} \text {, where } k=1, \ldots, 14 \text {. }
$$

For all criteria, it was assumed that the threshold function of strong preference is constant and equals 3 . This means that, if difference between the assessment of the ith variant (jth and ith examined construction enterprise) is greater than or equal to 3 (which therefore concerns the assessments for two variants, respectively 1 and 4, 1 and 5, 2 and 5), the $j$ th variant remains in relation between strong preference and the ith variant. Consequently, the $j t h$ variant is significantly better than the ith variant as far as the analysed criterion is concerned.

The threshold functions of veto for the criteria are defined as follows:

$v_{k}(x)=\left\{\begin{array}{ccc}4 & \text { for } & x \in\{1\} \\ 5 & \text { for } & x \in\{2,3,4,5\}\end{array}\right\}$ for criteria $f_{k}$,

where $k \in\{11,12,14\}$,

$v_{k}(x)=5$ for criteria $f_{k}$,

where $k=\{1,2,3,4,5,6,7,8,9,10,11,12,13\}$.

For three basic criteria mentioned in the definition of partnering and strongly emphasized in all works on the subject, namely criteria $f_{11}, f_{12}, f_{14}$, the veto threshold was defined for assessment value 1 at level 4 . This means that if for any of the three criteria mentioned above the assessment of the ith variant equals 5 and is higher than the assessment of the jth variant considering value 4, then, irrespective of other assessments (even if all other assessments of the $j t h$ variant are much higher than those of the $i$ th variant), the hypothesis of the dominance of variant $a^{j}$ over variant $a^{i}$ has to be rejected. If, for a given criterion (one of the three, i.e. $f_{11}, f_{12}, f_{14}$ ), the assessment of the ith variant assumes one of values 1, 2, 3, 4 and the assessment of the $j$ th variant is lower by at least 5 , then, irrespective of other assessments, the hypothesis of the dominance of variant $a^{j}$ over variant $a^{i}$ has to be rejected. The value 5 of the veto threshold was selected in order for veto not to work.

For the remaining criteria, if for a given criterion the assessment of the $j t h$ variant is lower by at least 5 than the assessment of the ith variant, then, irrespective of other assessments, the hypothesis of the dominance of variant $a^{j}$ over variant $a^{i}$ has to be rejected. The value of the veto threshold was selected in order for veto not to work.

To sum up, veto works only for assessments 1 and 5 and for criteria $f_{11}, f_{12}$, and $f_{14}$.

For the threshold functions defined in this way, one needs to check whether coherence conditions are fulfilled, i.e.

$$
\begin{array}{cl}
\forall a \in A & 0 \leq q_{k}\left(f_{k}(a)\right) \leq p_{k}\left(f_{k}(a)\right), \\
\forall a^{i}, a^{j} \in A & \frac{q_{k}\left(f_{k}\left(a^{j}\right)\right)-q_{k}\left(f_{k}\left(a^{i}\right)\right)}{f_{k}\left(a^{j}\right)-f_{k}\left(a^{i}\right)} \geq-1, \\
\forall a^{i}, a^{j} \in A & \frac{p_{k}\left(f_{k}\left(a^{j}\right)\right)-p_{k}\left(f_{k}\left(a^{i}\right)\right)}{f_{k}\left(a^{j}\right)-f_{k}\left(a^{i}\right)} \geq-1,
\end{array}
$$

for each $k=1, \ldots, 14$, where $\mathrm{A}$ - the group of the assessed variants (construction enterprises).

The first condition is fulfilled on the basis of the definition of threshold functions all of which are nondecreasing functions; it thus follows that they fulfil coherence criteria (the second and third condition).

The author's commission elaborated ConRel Construction Relationship Partnering software employing a computer programmer.

The application was made using the Visual Studio package. The data from construction enterprises being studied entered in the form of assessing particular parameters of relations with transactors in the microenvironment and are stored in an Access-type database. Calculations are performed in the MatLab package where the author implemented the ELECTRE III method algorithm. Input data are exported to the MatLab package using COM (Component Object Model Technologies). After calculations, data are repeatedly imported into the ConRel programme by means of COM technology. Input data and calculation results (credibility matrix, relation matrix and distillation results) can be exported to the Excel programme in accordance with the pattern elaborated by the user. 


\section{Individual Author's Methods of Selecting a Construction Enterprise for Partnering Cooperation}

The author has created two alternative methods of choosing a construction enterprise for partnering cooperation.

Method 1. The first method proposes the adoption of transactor's hierarchy from the most to the least important: 1) a subcontractor/the main contractor, 2) an investor/investor's representative, 3) building material supplier, 4) building equipment supplier. When choosing another construction enterprise for partnering cooperation, the given construction enterprise primarily analyses the level of partnering relations between that enterprise and other construction enterprises while its relations with equipment suppliers are the least important considering the fact that some enterprises have their own equipment. By applying the method proposed in our case and using the ELECTRE III method algorithm, we analyse the relations between a construction enterprise and its most important transactor. Next, when using the existing ratings (the descending and ascending distillation), we determine the group of enterprises which fulfil the established requirements. If this group is not a single-element, i.e. contains more than one construction enterprise, relation analysis is performed applying the ELECTRE III method algorithm along with the subsequent transactor from the list containing information on the hierarchy of a transactor. The procedure is repeated until the current group of enterprises contains a single element or until all transactors have been checked. If the procedure has ended because the current group is a single-element one, it is assumed that the enterprise which belongs to this group is a solution. If the procedure has ended because there are no more transactors, then, the outcome of the procedure is the current group of construction enterprises. One then either has to choose a construction enterprise for partnering cooperation oneself or randomly.

Example 1. This example analyses the level of partnering relations between construction enterprises and a subcontractor/the main contractor as the most important transactor in the hierarchy of transactors. The present analysis covered seven Polish construction enterprises. The Personal Information Protection Act means that their names are not given here. The data obtained from the enterprises being studied (the assessment of relation parameters and their importance on a five-point scale) are presented in Table 2 .

The credibility matrix was established (Table 3 ) and used for determining ratings by means of the descending or ascending distillation. The higher is the value of coefficient $\sigma_{i, j}$, the better are the ith and the $j$ th variants. For example, coefficients $\sigma_{6,3}, \sigma_{3,6}$ assume similar values, 0.81 and 0.87 respectively, so the solutions will presumably be equivalent. In the case of the ascending distillation (Table 4), these enterprises are equivalent and the best in rating. However, coefficient $\sigma_{3,2}=0.97$ is over twice as high as coefficient $\sigma_{2,3}=0.42$ which allows for an assumption that in the second enterprise, partnering relations are more underdeveloped than in the third one. In the two final ratings, the third enterprise is classified higher than the second one.

Analysis using the ELECTRE III method produced two ratings of the enterprises which allowed for a decision regarding the choice of a construction enterprise for partnering cooperation (Table 4). A level in Table 4 symbolizes a position in rating. Level 1 is the first position, 2 is the second, etc.

Table 2. Data on the enterprises studied (for example No. 1)

\begin{tabular}{|c|c|c|c|c|c|c|c|c|c|c|c|c|c|c|}
\hline \multicolumn{7}{|c|}{$\begin{array}{l}\text { Importance of relation } \\
\text { parameters for } \\
\text { the enterprise }\end{array}$} & \multirow[t]{2}{*}{$\begin{array}{c}\text { Criteri- } \\
\text { on } \\
f_{k}\end{array}$} & \multicolumn{7}{|c|}{$\begin{array}{l}\text { Level of enterprise } \\
\text { relations with the subcon- } \\
\text { tractor/main contractor }\end{array}$} \\
\hline$a^{1}$ & $a^{2}$ & $a^{3}$ & $a^{4}$ & $a^{5}$ & $a^{6}$ & $a^{\prime}$ & & $a^{1}$ & $a^{2}$ & $a^{3}$ & $a^{4}$ & $a^{5}$ & $a^{6}$ & $a^{7}$ \\
\hline 3 & 4 & 4 & 3 & 4 & 4 & 5 & $f_{1}$ & 5 & \begin{tabular}{|l|}
5 \\
\end{tabular} & \begin{tabular}{|l}
4 \\
\end{tabular} & \begin{tabular}{|l|}
3 \\
\end{tabular} & 3 & 5 & 5 \\
\hline 1 & 5 & 4 & 1 & 3 & 5 & 5 & $f_{2}$ & 4 & 5 & 3 & 3 & 4 & 5 & 5 \\
\hline 5 & 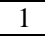 & 5 & 1 & 2 & 1 & 5 & $f_{3}$ & 5 & 3 & 4 & 3 & 4 & 1 & 4 \\
\hline 4 & 5 & 4 & 4 & 4 & 4 & 5 & $f_{4}$ & 4 & 2 & 3 & 3 & 3 & 5 & 5 \\
\hline 5 & 5 & 4 & 3 & 4 & 4 & 5 & $f_{5}$ & 5 & 3 & 5 & 3 & 5 & 1 & 4 \\
\hline 2 & 1 & 4 & 4 & 3 & 2 & 2 & $f_{6}$ & 5 & 2 & 5 & 3 & 2 & 5 & 2 \\
\hline 1 & 1 & 4 & 1 & 3 & 4 & 1 & $f_{7}$ & 1 & 1 & 5 & 1 & 4 & 5 & 1 \\
\hline 1 & 1 & 5 & 3 & 4 & $\underline{4}$ & 3 & $f_{8}$ & 2 & 1 & 5 & 2 & 5 & 5 & 3 \\
\hline 1 & 5 & 5 & 3 & 4 & 4 & 5 & $f_{9}$ & 5 & 2 & 5 & 3 & 3 & 5 & 5 \\
\hline 5 & 5 & 4 & 3 & 5 & 5 & 4 & $f_{10}$ & 2 & 2 & 4 & 3 & 4 & 5 & 5 \\
\hline 3 & 5 & 4 & 4 & 4 & 5 & 5 & $f_{11}$ & 4 & 3 & 4 & 3 & 4 & 5 & 5 \\
\hline 3 & 5 & 5 & 4 & 5 & 2 & 5 & $f_{12}$ & 3 & 3 & 5 & 3 & 4 & 5 & 5 \\
\hline 3 & 5 & 4 & 5 & 4 & 5 & 5 & $f_{13}$ & 4 & 2 & 4 & 4 & 3 & 5 & 5 \\
\hline 3 & 5 & 4 & 4 & 4 & 1 & 5 & $f_{14}$ & 5 & 3 & 5 & 3 & 4 & 3 & 5 \\
\hline
\end{tabular}

Table 3. Credibility matrix (for example No. 1)

\begin{tabular}{c|c|c|c|c|c|c|c}
\hline Enterprise & $a^{1}$ & $a^{2}$ & $a^{3}$ & $a^{4}$ & $a^{5}$ & $a^{6}$ & $a^{7}$ \\
\hline$a^{1}$ & 1 & 1 & 0.79 & 0.97 & 0.82 & 0.73 & 0.83 \\
\hline$a^{2}$ & 0.6 & 1 & 0.42 & 0.89 & 0.69 & 0.29 & 0.43 \\
\hline$a^{3}$ & 0.98 & 0.97 & 1 & 1 & 1 & 0.87 & 0.87 \\
\hline$a^{4}$ & 0.72 & 0.93 & 0.6 & 1 & 0.72 & 0.55 & 0.59 \\
\hline$a^{5}$ & 0.83 & 0.96 & 0.85 & 0.98 & 1 & 0.69 & 0.73 \\
\hline$a^{6}$ & 0.81 & 0.91 & 0.81 & 0.91 & 0.84 & 1 & 0.81 \\
\hline$a^{7}$ & 0.9 & 1 & 0.85 & 0.98 & 0.9 & 0.88 & 1 \\
\hline
\end{tabular}

Table 4. Distillation results (for example No. 1)

\begin{tabular}{c|c|c}
\hline Level & Descending distillation & Ascending distillation \\
\hline 1 & $a^{3}$ & $a^{3} ; a^{6} ; a^{7}$ \\
\hline 2 & $a^{7}$ & $a^{1}$ \\
\hline 3 & $a^{1} ; a^{5} ; a^{6}$ & $a^{5}$ \\
\hline 4 & $a^{2} ; a^{4}$ & $a^{2} ; a^{4}$ \\
\hline
\end{tabular}

Table 5. Relation matrix (for example No. 1)

\begin{tabular}{c|r|c|c|c|c|c|c}
\hline Enterprise & $a^{1}$ & $a^{2}$ & $a^{3}$ & $a^{4}$ & $a^{5}$ & $a^{6}$ & $a^{7}$ \\
\hline$a^{1}$ & 0 & 1 & -1 & 1 & 1 & -1 & -1 \\
\hline$a^{2}$ & -1 & 0 & -1 & 0 & -1 & -1 & -1 \\
\hline$a^{3}$ & 1 & 1 & 0 & 1 & 1 & 1 & 1 \\
\hline$a^{4}$ & -1 & 0 & -1 & 0 & -1 & -1 & -1 \\
\hline$a^{5}$ & -1 & 1 & -1 & 1 & 0 & -1 & -1 \\
\hline$a^{6}$ & 1 & 1 & -1 & 1 & 1 & 0 & -1 \\
\hline$a^{7}$ & 1 & 1 & -1 & 1 & 1 & 1 & 0 \\
\hline
\end{tabular}

The matrix of relations (Table 5) is based on the analysis of the ratings of results concerning the increasing and decreasing distillation. If value $r_{i, j}=0$ (the variants are equivalent), enterprises $i$ and $j$ are at the same level in both the descending and ascending distillation. This is the case with enterprises $a^{2}$ and $a^{4}$. However, if $r_{i, j}=1$ (the 
ith variant is better than the $j t h$ one), then, in one of the ratings, the ith enterprise is classified higher than the $j t h$ enterprise while in another rating, it is classified at the level of the $j$ th enterprise or higher. This is the case with enterprises $a^{3}$ and $a^{7}$. If $r_{i, j}=-1$ (the $i t h$ variant is worse than the $j t h$ one), then the $j$ th enterprise in one of the ratings classified at a higher level than the ith enterprise while in another rating, it is classified at the same level or higher than the ith enterprise. This is the case with enterprises $a^{7}$ and $a^{6}$. Consequently, definition $r_{i, j}$ provides that if $r_{i, j}=1$, then, $r_{j, i}=-1$. If $r_{i, j}=2$, then, in one of the ratings, the ith enterprise is at a higher level than the $j$ th one while in another rating, it is lower. Therefore, they are incomparable. As this situation does not occur in the example analysed, the collective rating does not branch out.

The numbers from 1 to 7 in Fig. 2 denote the numbers of construction enterprises (previously symbolised in Tables 2, 3, 4 and 5 as $a^{1}, a^{2}, a^{3}, \ldots a^{7}$ ).

Enterprise No. 3 is placed in the highest position of collective rating because in the descending distillation, it is the best and in the ascending distillation it is at the same level as enterprise No. 6 .

The next position is occupied by enterprise No. 7 as the best one in the descending distillation (disregarding enterprise No. 3 included in the collective rating) while in the ascending distillation it is at the highest level along with enterprise No. 6. Since in the ascending distillation it is at the highest level and in the descending distillation is currently the best, it occupies the next position. By repeating this procedure, the collective rating of construction enterprises is created (Fig. 2).

In the first method, the decision-maker may assume a different hierarchy of transactor importance.
Descending distillation Ascending distillation Collective rating
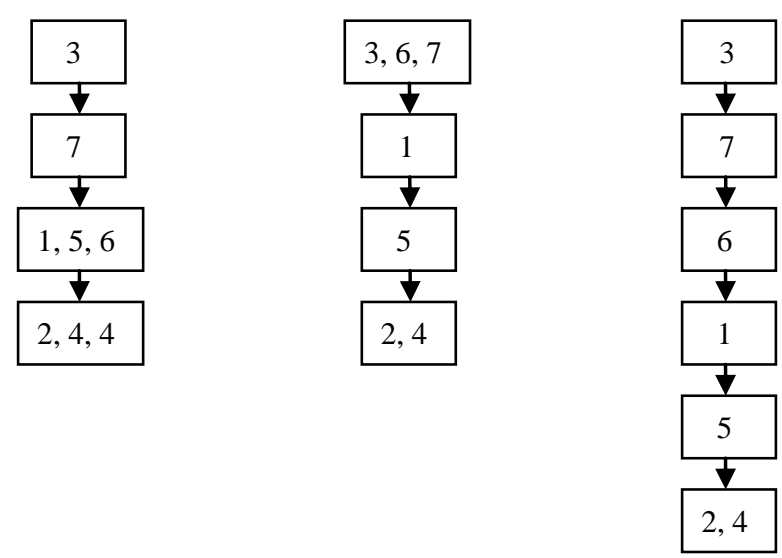

Fig. 2. A graphic representation of results in example No. 1

Method 2. In the second method, the author proposes that collective ratings should be made for each of the transactors (four collective ratings) on the basis of the descending and ascending distillation. Next, by applying similar procedures to the collective ratings for particular transactors as those used to create these ratings, we obtain global rating allowing the selection of a satisfying solution. The procedure is presented in the example below.

Example 2. Eight Polish construction enterprises were selected for analysis. The Personal Information Protection Act means that their names are not given here.

The data obtained from the enterprises analysed are presented in Table 6. The calculations of interpreting the results of credibility and the relation matrix are analogous to example No. 1 and are therefore not presented here. The calculation results conforming to the method algorithm are provided in Tables 7-10 and Figs. 3-6 present their interpretation in a graphical form.

Table 6. Data from the enterprises analysed (example No. 2)

\begin{tabular}{|c|c|c|c|c|c|c|c|c|c|c|c|c|c|c|c|c|c|c|c|c|c|c|c|c|c|c|c|c|c|c|c|c|c|c|c|c|c|c|c|c|c|}
\hline \multicolumn{8}{|c|}{$\begin{array}{l}\text { Importance of relation } \\
\text { parameters for } \\
\text { enterprises }\end{array}$} & & \multicolumn{8}{|c|}{$\begin{array}{l}\text { Level of enterprise } \\
\text { relations with } \\
\text { materials supplier }\end{array}$} & \multicolumn{8}{|c|}{$\begin{array}{l}\text { Level of enterprise } \\
\text { relations with } \\
\text { equipment supplier }\end{array}$} & \multicolumn{8}{|c|}{$\begin{array}{l}\text { Level of enterprise } \\
\text { relations with a } \\
\text { subcontractor/ the } \\
\text { main contractor }\end{array}$} & \multicolumn{8}{|c|}{$\begin{array}{l}\text { Level of enterprise } \\
\text { relations with an } \\
\text { investor/investor's } \\
\text { representative }\end{array}$} \\
\hline & & & & & & & & & & $a^{1}$ & & & & & & & & & & & & & & & & & & & & & & & & & & & & & & & $a$ \\
\hline 5 & 4 & 3 & 2 & 3 & 2 & & & & $f_{1}$ & 3 & 4 & 4 & 3 & 3 & 3 & 3 & 3 & 3 & 3 & 3 & 3 & 3 & 1 & 1 & 4 & 3 & 4 & 4 & 3 & 4 & 4 & 4 & 5 & 3 & 3 & 5 & 4 & 4 & 4 & 4 & 3 \\
\hline 5 & 4 & & & & & & & & & & & & $\rightarrow$ & & 5 & 2 & 5 & 4 & 2 & 4 & 4 & - & $\rightarrow$ & 3 & & 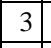 & 3 & & & 4 & 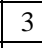 & & 5 & & 3 & $\rightarrow$ & 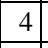 & 4 & 2 & 4 & \\
\hline 5 & 5 & 3 & 4 & 2 & 4 & & & & & 4 & 5 & 4 & 2 & 4 & 5 & 4 & 4 & 5 & 3 & 4 & 1 & 3 & 4 & 4 & 4 & 1 & \begin{tabular}{|l|}
4 \\
\end{tabular} & 4 & 3 & 3 & 4 & 5 & 5 & 1 & 4 & 4 & 3 & 3 & 4 & 2 & 3 \\
\hline 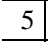 & 4 & & & & & & & & & & & & 4 & & 5 & 1 & 2 & 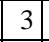 & 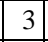 & 2 & 4 & 3 & 4 & 1 & & 5 & 3 & & & 3 & & 2 & 3 & 5 & 3 & 5 & 4 & 3 & 5 & 4 & 2 \\
\hline 5 & 4 & 4 & 4 & 3 & 3 & & & & & 3 & 4 & 3 & 3 & 3 & 4 & 4 & 2 & 1 & 2 & 3 & 4 & 3 & 3 & 4 & 4 & 3 & 5 & 3 & 3 & 3 & 3 & 3 & 3 & 3 & 3 & 3 & 4 & 3 & 4 & 3 & 4 \\
\hline 5 & 4 & & 3 & & 3 & & & & & 4 & 4 & 4 & 1 & 3 & 4 & 3 & 4 & 2 & 4 & 4 & 1 & 4 & 3 & 4 & 3 & 5 & 5 & 3 & & 4 & 4 & & 4 & 5 & 4 & 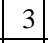 & 2 & 3 & 4 & 2 & 5 \\
\hline 5 & 4 & 4 & 3 & 3 & 5 & & & & & 1 & 3 & 3 & 2 & 4 & 5 & 4 & 2 & 1 & 3 & 4 & 2 & 3 & 3 & 4 & 2 & 1 & 5 & 3 & 3 & 3 & 4 & 3 & 3 & 1 & 2 & 4 & 1 & 3 & 4 & 3 & 2 \\
\hline 5 & 5 & 4 & 4 & 4 & 3 & & & & & 3 & 4 & 2 & 4 & 3 & 3 & 2 & 5 & 3 & 4 & 2 & 3 & 3 & 2 & 3 & 5 & 5 & 5 & 3 & 4 & 3 & 4 & 4 & 4 & 5 & 4 & & 3 & 3 & 5 & 5 & 4 \\
\hline 5 & 5 & 3 & 3 & 4 & 5 & & & & $\mathrm{f}$ & 5 & 4 & 3 & 4 & 4 & 5 & 3 & 4 & 5 & 4 & 3 & 3 & 3 & 4 & 4 & 4 & 5 & 5 & 3 & 4 & 3 & 4 & 2 & 3 & 5 & 4 & 3 & 3 & 4 & 4 & 1 & 3 \\
\hline 5 & 4 & 5 & 4 & 4 & 4 & & & & & 5 & 4 & 5 & 3 & 4 & 5 & 2 & 4 & 2 & 4 & 5 & 3 & 3 & 4 & 3 & 2 & 5 & \begin{tabular}{|l|}
4 \\
\end{tabular} & 5 & 4 & 3 & 5 & 3 & 4 & 5 & 3 & 5 & 3 & 3 & 5 & 3 & 5 \\
\hline 4 & 4 & 4 & 4 & 4 & 4 & & & & & 1 & 4 & 3 & 3 & 4 & 4 & 2 & 5 & 1 & 4 & 3 & 3 & 4 & 3 & 2 & 2 & 4 & \begin{tabular}{|l|}
4 \\
\end{tabular} & 3 & 4 & 3 & 4 & 4 & 5 & 4 & 3 & 3 & 3 & 3 & \begin{tabular}{|l|}
4 \\
\end{tabular} & \begin{tabular}{|l|}
5 \\
\end{tabular} & 4 \\
\hline 5 & 5 & 4 & 4 & 4 & 4 & & & & & 2 & 3 & 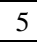 & 3 & 3 & 5 & 3 & 2 & 2 & 3 & 5 & 2 & 3 & 3 & 3 & 1 & 5 & 5 & 4 & 4 & 4 & 4 & 3 & 3 & 5 & 3 & 3 & 3 & 3 & 4 & \begin{tabular}{|l|}
4 \\
\end{tabular} & 4 \\
\hline 5 & 4 & 5 & 5 & 4 & 5 & 4 & & & $\mathrm{f}_{1}$ & 5 & 4 & 3 & 5 & 4 & 3 & כ & 4 & 5 & 4 & 4 & 5 & 4 & 2 & 4 & 2 & 5 & \begin{tabular}{|l|}
4 \\
\end{tabular} & 3 & 3 & 3 & 4 & 3 & 3 & 5 & \begin{tabular}{|l|}
4 \\
\end{tabular} & 4 & 5 & 4 & 4 & 3 & 3 \\
\hline 5 & 4 & 4 & 5 & 4 & 3 & & & & $\mathrm{f}_{1}$ & 3 & 5 & 4 & 4 & 4 & 4 & 1 & 5 & 3 & 4 & 4 & 3 & 4 & 3 & 5 & 4 & 4 & 5 & 4 & 3 & 4 & 4 & 3 & 5 & 5 & 4 & 4 & 3 & 4 & 4 & 3 & \\
\hline
\end{tabular}


Table 7. The matrix of credibility (A), relations (C) and distillation results (B). The transactor constituting the subject of analysis: materials supplier (example No. 2)

$\underline{\text { A. }}$

\begin{tabular}{c|c|c|c|c|c|c|c|c}
\hline \multicolumn{10}{c}{ Credibility matrix } \\
\hline Enterprise & $a^{1}$ & $a^{2}$ & $a^{3}$ & $a^{4}$ & $a^{5}$ & $a^{6}$ & $a^{7}$ & $a^{8}$ \\
\hline$a^{1}$ & 1 & 0.76 & 0.81 & 0.88 & 0.81 & 0.64 & 0.86 & 0 \\
\hline$a^{2}$ & 0.97 & 1 & 0.92 & 1 & 0.98 & 0.85 & 0.98 & 0.95 \\
\hline$a^{3}$ & 0.92 & 0.83 & 1 & 0.85 & 0.91 & 0.71 & 0.91 & 0.79 \\
\hline$a^{4}$ & 0.83 & 0.74 & 0.76 & 1 & 0.81 & 0.64 & 0.83 & 0.78 \\
\hline$a^{5}$ & 0.95 & 0.91 & 0.9 & 1 & 1 & 0.8 & 0.98 & 0.86 \\
\hline$a^{6}$ & 0.96 & 0.98 & 1 & 0.96 & 1 & 1 & 0.96 & 0.91 \\
\hline$a^{7}$ & 0.78 & 0 & 0.75 & 0.73 & 0.75 & 0.51 & 1 & 0 \\
\hline & 0.95 & 0.84 & 0.85 & 0.92 & 0.87 & 0.68 & 0.88 & 1 \\
\hline B. & \multicolumn{10}{|c}{} \\
\hline
\end{tabular}

\begin{tabular}{c|c|c}
\hline \multicolumn{3}{c}{ B. } \\
\hline \multicolumn{3}{|c}{ Distillation results } \\
\hline Level & Descending distillation & Ascending distillation \\
\hline 1 & $a^{6}$ & $a^{2} ; a^{6}$ \\
\hline 2 & $a^{2}$ & $a^{3} ; a^{5} ; a^{8}$ \\
\hline 3 & $a^{5} ; a^{8}$ & $a^{1} ; a^{4}$ \\
\hline 4 & $a^{1} ; a^{3} ; a^{4} ; a^{7}$ & $a^{7}$ \\
\hline \multicolumn{3}{|c}{} \\
\hline
\end{tabular}

\begin{tabular}{c|r|r|r|r|r|r|r|r}
\hline \multicolumn{10}{c}{ Relation matrix } \\
\hline Enterprise & $a^{1}$ & $a^{2}$ & $a^{3}$ & $a^{4}$ & $a^{5}$ & $a^{6}$ & $a^{7}$ & $a^{8}$ \\
\hline$a^{1}$ & 0 & -1 & -1 & 0 & -1 & -1 & 1 & -1 \\
\hline$a^{2}$ & 1 & 0 & 1 & 1 & 1 & -1 & 1 & 1 \\
\hline$a^{3}$ & 1 & -1 & 0 & 1 & -1 & -1 & 1 & -1 \\
\hline$a^{4}$ & 0 & -1 & -1 & 0 & -1 & -1 & 1 & -1 \\
\hline$a^{5}$ & 1 & -1 & 1 & 1 & 0 & -1 & 1 & 0 \\
\hline$a^{6}$ & 1 & 1 & 1 & 1 & 1 & 0 & 1 & 1 \\
\hline$a^{7}$ & -1 & -1 & -1 & -1 & -1 & -1 & 0 & -1 \\
\hline$a^{8}$ & 1 & -1 & 1 & 1 & 0 & -1 & 1 & 0 \\
\hline
\end{tabular}

Table 8. The matrix of credibility (A), relations (C) and distillation results (B). The transactor constituting the subject of analysis: equipment supplier (example No. 2)

A.

Credibility matrix

\begin{tabular}{c|c|c|c|c|c|c|c|c}
\hline Enterprise & $a^{1}$ & $a^{2}$ & $a^{3}$ & $a^{4}$ & $a^{5}$ & $a^{6}$ & $a^{7}$ & $a^{8}$ \\
\hline$a^{1}$ & 1 & 0.71 & 0.61 & 0.8 & 0.71 & 0.76 & 0.69 & 0.77 \\
\hline$a^{2}$ & 0.95 & 1 & 0.85 & 0.92 & 0.98 & 0.95 & 0.88 & 0.9 \\
\hline$a^{3}$ & 0.94 & 0.94 & 1 & 0.91 & 0.98 & 0.96 & 0.95 & 0.87 \\
\hline$a^{4}$ & 0.87 & 0.76 & 0.66 & 1 & 0.79 & 0.81 & 0.74 & 0.82 \\
\hline$a^{5}$ & 0.92 & 0.97 & 0.85 & 0.98 & 1 & 0.95 & 0.9 & 0.92 \\
\hline$a^{6}$ & 0.86 & 0.81 & 0.77 & 0.8 & 0.82 & 1 & 0.81 & 0.76 \\
\hline$a^{7}$ & 0.9 & 0.85 & 0.84 & 0.87 & 0.88 & 0.88 & 1 & 0.91 \\
\hline$a^{8}$ & 0.83 & 0.72 & 0 & 0.77 & 0.75 & 0.78 & 0.79 & 1 \\
\hline B. & \multicolumn{10}{c}{}
\end{tabular}

\begin{tabular}{l|c|c}
\hline \multicolumn{3}{c}{ B. } \\
\hline \multicolumn{3}{|c}{ Distillation results } \\
\hline Level & Descending distillation & Ascending distillation \\
\hline 1 & $a^{3}$ & $a^{2} ; a^{3} ; a^{5} ; a^{7}$ \\
\hline 2 & $a^{2} ; a^{5}$ & $a^{6}$ \\
\hline 3 & $a^{7}$ & $a^{4} ; a^{8}$ \\
\hline 4 & $a^{1} ; a^{4} ; a^{6} ; a^{8}$ & $a^{1}$ \\
\hline \multicolumn{3}{c}{}
\end{tabular}

\begin{tabular}{c|c|c|c|c|c|c|c|c}
\hline \multicolumn{10}{c}{ Relation matrix } \\
\hline Enterprise & $a^{1}$ & $a^{2}$ & $a^{3}$ & $a^{4}$ & $a^{5}$ & $a^{6}$ & $a^{7}$ & $a^{8}$ \\
\hline$a^{1}$ & 0 & -1 & -1 & -1 & -1 & -1 & -1 & -1 \\
\hline$a^{2}$ & 1 & 0 & -1 & 1 & 0 & 1 & 1 & 1 \\
\hline$a^{3}$ & 1 & 1 & 0 & 1 & 1 & 1 & 1 & 1 \\
\hline$a^{4}$ & 1 & -1 & -1 & 0 & -1 & -1 & -1 & 0 \\
\hline$a^{5}$ & 1 & 0 & -1 & 1 & 0 & 1 & 1 & 1 \\
\hline$a^{6}$ & 1 & -1 & -1 & 1 & -1 & 0 & -1 & 1 \\
\hline$a^{7}$ & 1 & -1 & - & 1 & -1 & - & 0 & 1 \\
\hline$a^{8}$ & 1 & -1 & -1 & 0 & -1 & -1 & -1 & 0 \\
\hline
\end{tabular}

Table 9. The matrix of credibility (A), relations (C) and distillation results (B). The transactor constituting the subject of analysis: a subcontractor/the main contractor (example No. 2)

\begin{tabular}{|c|c|c|c|c|c|c|c|c|}
\hline \multicolumn{9}{|c|}{ Credibility matrix } \\
\hline Enterprise & $a^{1}$ & $a^{2}$ & $a^{3}$ & $a^{4}$ & $a^{5}$ & $a^{6}$ & $a^{7}$ & $a^{8}$ \\
\hline$a^{1}$ & 1 & 0.78 & 0.85 & 0.9 & 0.9 & 0.86 & 0.88 & 0.77 \\
\hline$a^{2}$ & 0.94 & 1 & 0.94 & 1 & 1 & 0.94 & 0.98 & 0.92 \\
\hline$a^{3}$ & 0.79 & 0.71 & 1 & 0.94 & 0.98 & 0.93 & 0.91 & 0.88 \\
\hline$a^{4}$ & 0.88 & 0.76 & 0.89 & 1 & 0.95 & 0.88 & 0.91 & 0.8 \\
\hline$a^{5}$ & 0.72 & 0.69 & 0.92 & 0.91 & 1 & 0.84 & 0.91 & 0.85 \\
\hline$a^{6}$ & 0.95 & 0.86 & 0.97 & 1 & 1 & 1 & 0.95 & 0.9 \\
\hline$a^{7}$ & 0.69 & 0.71 & 0.8 & 0.84 & 0.92 & 0.76 & 1 & 0.84 \\
\hline$a^{8}$ & 0.79 & 0.8 & 0.95 & 0.93 & 0.98 & 0.89 & 0.98 & 1 \\
\hline
\end{tabular}

\begin{tabular}{|c|c|c|c|c|c|c|c|c|}
\hline \multicolumn{9}{|c|}{ Distillation results } \\
\hline Level & \multicolumn{4}{|c|}{ Descending distillation } & \multicolumn{4}{|c|}{ Ascending distillation } \\
\hline 1 & \multicolumn{4}{|c|}{$a^{2}$} & \multicolumn{4}{|c|}{$a^{1} ; a^{2} ; a^{6} ; a^{8}$} \\
\hline 2 & \multicolumn{4}{|c|}{$a^{1} ; a^{6}$} & \multicolumn{4}{|c|}{$a^{3} ; a^{4}$} \\
\hline 3 & \multicolumn{4}{|c|}{$a^{3} ; a^{4} ; a^{5} ; a^{7} ; a^{8}$} & \multicolumn{4}{|c|}{$a^{5} ; a^{7}$} \\
\hline \multicolumn{9}{|c|}{ 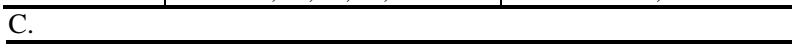 } \\
\hline \multicolumn{9}{|c|}{ Relation matrix } \\
\hline Enterprise & $a^{1}$ & $a^{2}$ & $a^{3}$ & $a^{4}$ & $a^{5}$ & $a^{6}$ & $a^{7}$ & $a^{8}$ \\
\hline$a^{1}$ & 0 & -1 & 1 & 1 & 1 & 0 & 1 & 1 \\
\hline$a^{2}$ & 1 & 0 & 1 & 1 & 1 & 1 & 1 & 1 \\
\hline$a^{3}$ & -1 & -1 & 0 & 0 & 1 & -1 & 1 & -1 \\
\hline$a^{4}$ & -1 & -1 & 0 & 0 & 1 & -1 & 1 & -1 \\
\hline$a^{5}$ & -1 & -1 & -1 & -1 & 0 & -1 & 0 & -1 \\
\hline$a^{6}$ & 0 & -1 & 1 & 1 & 1 & 0 & 1 & 1 \\
\hline$a^{7}$ & -1 & -1 & -1 & -1 & 0 & -1 & 0 & -1 \\
\hline$a^{8}$ & -1 & -1 & 1 & 1 & 1 & -1 & 1 & 0 \\
\hline
\end{tabular}

Table 10. The matrix of credibility (A), relations (C) and distillation results (B). The transactor constituting the subject of analysis: an investor/investor's representative (example No. 2)

\begin{tabular}{|c|c|c|c|c|c|c|c|c|}
\hline \multicolumn{9}{|c|}{ Credibility matrix } \\
\hline Enterprise & $a^{1}$ & $a^{2}$ & $a^{3}$ & $a^{4}$ & $a^{5}$ & $a^{6}$ & $a^{7}$ & $a^{8}$ \\
\hline$a^{I}$ & 1 & 0.9 & 0.83 & 0.93 & 0.9 & 0.83 & 0.87 & 0.9 \\
\hline$a^{2}$ & 0.79 & 1 & 0.83 & 0.98 & 0.98 & 0.79 & 0.87 & 0.83 \\
\hline$a^{3}$ & 0.78 & 0.98 & 1 & 0.98 & 1 & 0.87 & 0.89 & 0.86 \\
\hline$a^{4}$ & 0.68 & 0.88 & 0.8 & 1 & 0.9 & 0.69 & 0.84 & 0.76 \\
\hline$a^{5}$ & 0.73 & 0.95 & 0.86 & 0.98 & 1 & 0.73 & 0.89 & 0.8 \\
\hline$a^{6}$ & 0.93 & 1 & 0.97 & 0.97 & 0.97 & 1 & 0.92 & 0.92 \\
\hline$a^{7}$ & 0.69 & 0.81 & 0.78 & 0.86 & 0.86 & 0.71 & 1 & 0.73 \\
\hline$a^{8}$ & 0.83 & 0.98 & 0.83 & 0.92 & 0.98 & 0.85 & 0.91 & 1 \\
\hline
\end{tabular}

\begin{tabular}{|c|c|c|c|c|c|c|c|c|}
\hline \multicolumn{9}{|c|}{ Distillation results } \\
\hline Level & \multicolumn{4}{|c|}{ Descending distillation } & \multicolumn{4}{|c|}{ Ascending distillation } \\
\hline 1 & \multicolumn{4}{|c|}{$a^{6}$} & \multicolumn{4}{|c|}{$a^{1} ; a^{3} ; a^{6} ; a^{8}$} \\
\hline 2 & \multicolumn{4}{|c|}{$a^{1} ; a^{8}$} & \multicolumn{4}{|c|}{$a^{2}$} \\
\hline 3 & \multicolumn{4}{|c|}{$a^{3}$} & \multicolumn{4}{|c|}{$a^{5} ; a^{7}$} \\
\hline 4 & \multicolumn{4}{|c|}{$a^{2} ; a^{4} ; a^{5} ; a^{7}$} & \multicolumn{4}{|c|}{$a^{4}$} \\
\hline \multicolumn{9}{|l|}{ C. } \\
\hline \multicolumn{9}{|c|}{ Relation matrix } \\
\hline Enterprise & $a^{1}$ & $a^{2}$ & $a^{3}$ & $a^{4}$ & $a^{5}$ & $a^{6}$ & $a^{7}$ & $a^{8}$ \\
\hline$a^{1}$ & 0 & 1 & 1 & 1 & 1 & -1 & 1 & 0 \\
\hline$a^{2}$ & -1 & 0 & -1 & 1 & 1 & -1 & 1 & -1 \\
\hline$a^{3}$ & -1 & 1 & 0 & 1 & 1 & -1 & 1 & -1 \\
\hline$a^{4}$ & -1 & -1 & -1 & 0 & -1 & -1 & -1 & -1 \\
\hline$a^{5}$ & -1 & -1 & -1 & 1 & 0 & -1 & 0 & -1 \\
\hline$a^{6}$ & 1 & 1 & 1 & 1 & 1 & 0 & 1 & 1 \\
\hline$a^{7}$ & -1 & -1 & -1 & 1 & 0 & -1 & 0 & -1 \\
\hline$a^{8}$ & 0 & 1 & 1 & 1 & 1 & -1 & 1 & 0 \\
\hline
\end{tabular}


Descending distillation Ascending distillation Collective rating
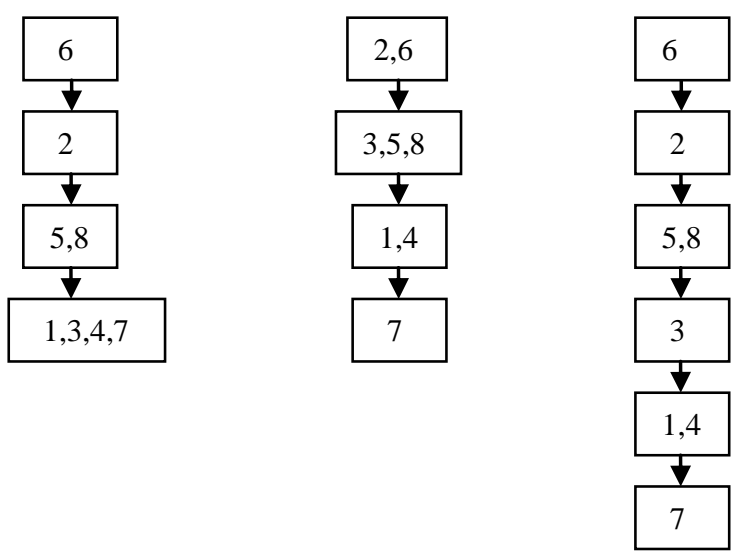

Fig. 3. A graphic representation of results (example No. 2). The transactor constituting the subject of analysis: material supplier

Descending distillation Ascending distillation Collective rating
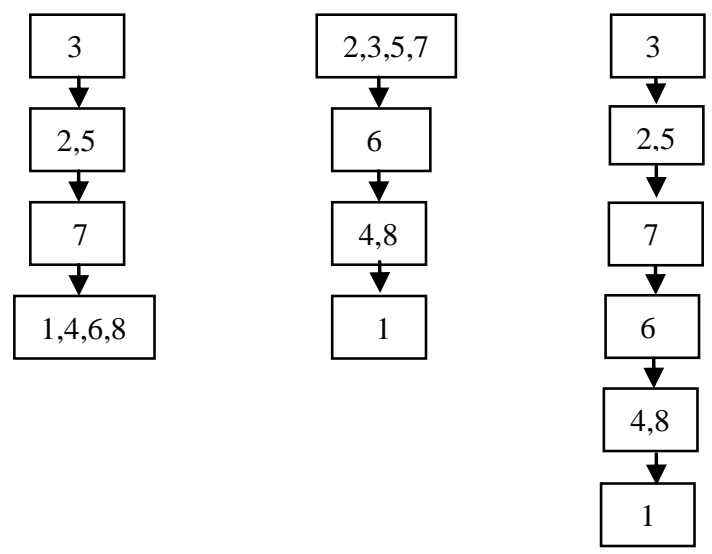

Fig. 4. A graphic representation of results (example No. 2). The transactor constituting the subject of analysis: equipment supplier

Descending distillation Ascending distillation Collective rating
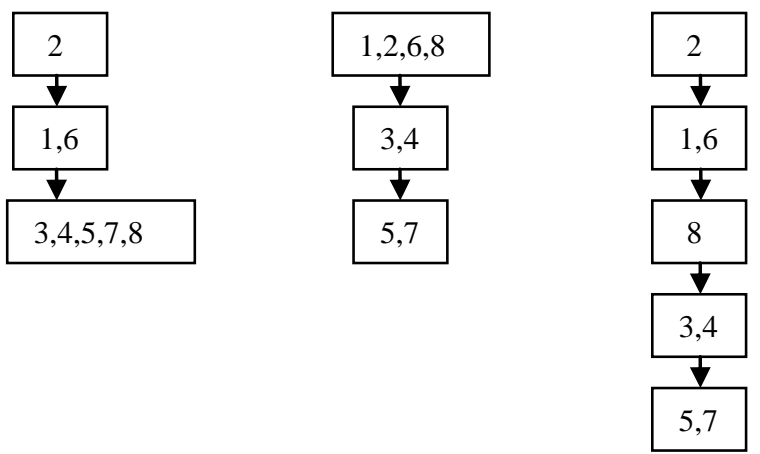

Fig. 5. A graphic representation of results (example No. 2). The transactor constituting the subject of analysis: a subcontractor/the main contractor

The obtained results allowed global rating (Fig. 7) to be created. The numbers from 1 to 7 in Figs 3 to 7 denote the numbers of construction enterprises (previously symbolized in Tables 6-10 as $a^{1}, a^{2}, a^{3}, \ldots a^{7}$ ).
Descending distillation Ascending distillation Collective rating
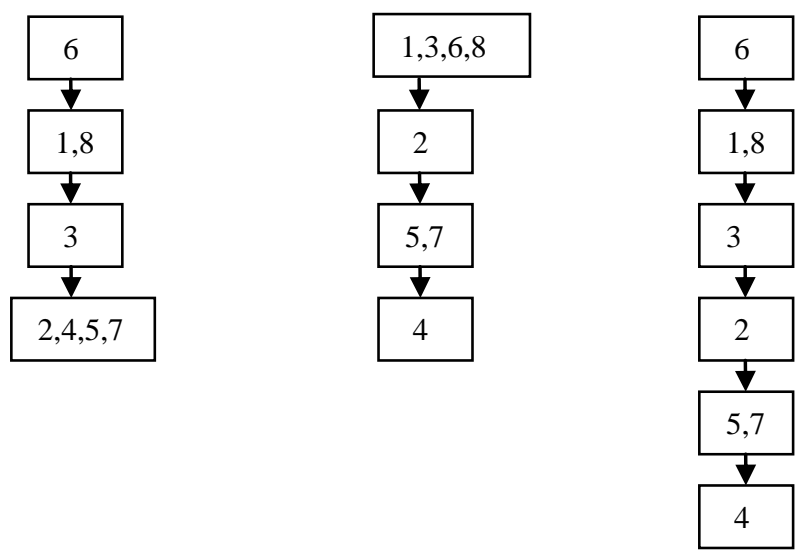

Fig. 6. A graphic representation of results (example No. 2). The transactor constituting the subject of analysis: an investor/investor's representative

The first layer contains the best elements. They are not comparable with one another. These are enterprises 2 , 6, and 3 (Fig. 7) and potential solutions which one has to check at one's own discretion. If one decided in favour of enterprise No. 2, then enterprises No. 1 and No. 8 would require checking because they are not comparable. If one decided in favour of enterprise No. 6, then enterprise No. 5 would require checking as it is not comparable to enterprise No. 6. It is also not comparable to enterprise No. 7; however, because enterprise No. 5 is better than No. 7, it suffices to check only No. 5. If one decided in favour of enterprise No. 3, enterprises $1,5,8$ would need checking at one's own discretion whether they are not better. These are suggestions for a construction enterprise on the basis of which the enterprise has to make a decision.

Global rating

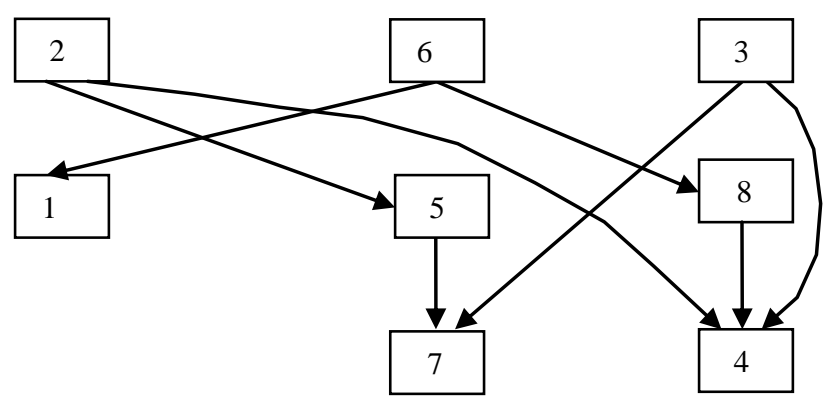

Fig. 7. The final graph of results (example No. 2)

The problem of selecting construction enterprises that would be the best for partnering cooperation in terms of partnering relations has been solved.

\section{Conclusions}

The present Author has elaborated two alternative methods of selecting a subcontractor and both are based on the ELECTRE III method algorithm. The developed methods support a decision-making system of a construction enterprise as regards the choice of another construction enterprise for partnering cooperation. The first method is more 
preferable due to a smaller number of incomparable solutions considering the final result. Moreover, the second method is more labour-intensive. The calculations applicable in both methods can be performed using the ConRel software created at the Cracow University of Technology.

\section{References}

Associated General Contractors of America (AGC). 1991. Partnering: A Concept for Success. AGC, Washington, USA.

Azar, S.; Azar, J.-M.; Hauglustaine, J.-M. 2001. Multicriteria and multiple actors tool aiding to optimise building envelope at the architectural sketch design, Informatica 12(1): 3-24.

Bayliss, R.; Cheung, S. O.; Suen, H. C. H.; Wong, S. P. 2004. Effective tools in construction: a case study on MTRC TKE contract 604 in Hong Kong, International Journal of Project Management 22(3): 253-263. doi:10.1016/S0263-7863(03)00069-3

Beach, R.; Webster, M.; Campbell, K. M. 2005. An evaluation of partnership development in the construction industry, International Journal of Project Management 23(8): 611621. doi:10.1016/j.ijproman.2005.04.001

Bennett, J.; Jayes, S. 1998. The Seven Pillars of Partnering, Reading Construction Forum Partnering Task Force, University of Reading. London: Thomas Telford.

Black, C.; Akintoye, A.; Fitzgerald, E. 2000. An analysis of success factors and benefits of partnering in construction, International Journal of Project Management 18(6): 423434. doi:10.1016/S0263-7863(99)00046-0

Bresnen, M.; Marshall, N. 2000. Partnering in construction: A critical review of issues, problems and dilemmas, Construction Management and Economics 18(2): 229-237. doi:10.1080/014461900370852

Cavallo, A.; Norese, M. F. 2001. GIS and multicriteria analysis to evaluate and map erosion and landslide hazards, Informatica 12(1): 25-44.

Chan, P.; Cooper, R.; Tzortzopoulos, P. 2005. Organizational learning: conceptual challenges from a project perspective, Construction Management and Economics 23(9): 747-756. doi:10.1080/01446190500127021

Cheng, E. W. L.; Li, H. 2004. Development of a practical model of partnering for construction projects, Journal of Construction Engineering and Management 130(6): 790-798. doi:10.1061/(ASCE)0733-9364(2004)130:6(790)

Cheung, S. O.; Suen, H. C. H.; Cheung, K. K. W. 2003a. An automated partnering monitoring system - Partnering Temperature Index, Automation in Construction 12(3): 331-345. doi:10.1016/S0926-5805(02)00108-5

Cheung, S. O.; Ng, T. S. T.; Wong, S. P.; Suen, H. C. H. 2003 b. Behavioral aspects in construction partnering, International Journal of Project Management 21(5): 333-343. doi:10.1016/S0263-7863(02)00052-2

Cheung, S. O. 2007. Bounded rationality, opportunism and trust in co-operative contracting, in Proceedings of the $4^{\text {th }} \mathrm{In}$ ternational Structural Engineering and Construction Conference (ISEC-4) 26-28.09.2007, Melbourne, Australia, $1537-1542$

Construction Industry Institute (CII). 1991. In search of partnering excellence. Special Publication No. 17-1, Report by the Partnering Task Force of CII, Austin, Texas, USA.

Drejer, I.; Vinding, A. L. 2006. Organisation, 'anchoring' of knowledge, and innovative activity in construction, Con- struction Management and Economics 24(9): 921-931. doi:10.1080/01446190600799166

Glagola, C.R.; Sheedy, W.M. 2002. Partnering on defense contracts, Journal of Construction Engineering and Management 128(2): 127-138. doi:10.1061/(ASCE)0733-9364(2002)128:2(127)

Kapliński, O. 2008. Development and usefulness of planning techniques and decision making foundations on the example of construction enterprises in Poland, Technological and Economic Development of Economy 14(4): 492-502. doi:10.3846/1392-8619.2008.14.492-502

Kapliński, O. 2009. Information technology in the development of the Polish construction industry, Technological and Economic Development of Economy 15(3): 437-452. doi:10.3846/1392-8619.2009.15.437-452

Kapliński, O.; Werner, W.; Kosecki, A.; Biernacki, J.; Kuczmarski. F. 2002. Current state and perspectives of research on construction management and mechanization in Poland, Journal of Civil Engineering and Management 8(4): 221-230.

Koraltan, S. B.; Dikbas, A. 2002. An assessment of the applicability of partnering in the Turkish construction sector, Construction Management and Economics 20(4): 315321. doi:10.1080/01446190210125554

Kululanga, G. K.; Kuotcha, W.; McCaffer, R.; Edum-Fotwe, F. 2001. Construction contractors' claim process framework, Journal of Construction Engineering and Management 127(4): 309-314. doi:10.1061/(ASCE)0733-9364(2001)127:4(309)

Kumaraswamy, M. M.; Ling, F. Y. Y.; Rahman, M. M.; Phng, S. T. 2005. Constructing relationally integrated teams, Journal of Construction Engineering and Management 131(10): 1076-1086. doi:10.1061/(ASCE)0733-9364(2005)131:10(1076)

Kwan, A. Y.; Ofori, G. 2001. Chinese culture and successful implementation of partnering in Singapore's construction industry, Construction Management and Economics 19(6): 619-632. doi:10.1080/01446190110062087

Lipshitz, R.; Popper, M.; Friedman, V. J. 2002. A multifacet model of organizational learning, Journal of Applied Behavioral Science 38 (1): 78-98. doi:10.1177/0021886302381005

Mróz, T. M.; Thiel, T. 2005. Evaluation of a heating system for buildings using multiple criteria decision analysis, $\mathrm{Ar}$ chives of Civil Engineering 51(2): 281-298.

Ng, S. T.; Rose, T. M.; Mak, M. Y.; Chen, S. E. 2002. Problematic issues associated with project partnering - the contractor perspective, International Journal of Project Management 20(6): 437-449. doi:10.1016/S0263-7863(01)00025-4

Nyström, J. 2008. A quasi-experimental evaluation of partnering, Construction Management and Economics 26(5): 531-541. doi:10.1080/01446190802036144

Phua, F. T. T.; Rowlinson, S. 2004. Operationalizing culture in construction management research: a social identity perspective in the Hong Kong contex, Construction Management and Economics 22(11): 913-925. doi:10.1080/01446190310001631000

Plebankiewicz, E. 2010. Construction contractor prequalification from Polish clients' perspective, Journal of Civil Engineering and Management 16(1): 57-64. doi:10.3846/jcem.2010.05

Pryke, S. D. 2004. Analysing construction project coalitions: exploring the application of social network analysis, Con- 
struction Management and Economics 22(10): 787-797. doi:10.1080/0144619042000206533

Radziszewska-Zielina, E. 2008a. A building enterprise on the market, Economics and Business Management, Journal for Economics Theory and Practice 6(1): 33-43.

Radziszewska-Zielina, E. 2008b. Barriers to the application of the partnering approach by polish construction enterprises, in Quality, Environment, Health Protection and Safety Management Development Trends, International scientific conference 02-06.09.2008, CEMAKS, Neum, Bosnia and Hercegovina, 261-266.

Radziszewska-Zielina, E. 2008c. Modeling of the partnering relations of construction enterprises, Quality Innovation Prosperity 12(2): 27-40.

Radziszewska-Zielina, E. 2010a. Analysis of the Impact of the level of partnering relations on the selected indexes of success of Polish construction enterprises, Inzinerine Ekonomika - Engineering Economics (3): 324-335.

Radziszewska-Zielina, E. 2010b. Analysis of the partnering relations of Polish, Slovak and Ukrainian construction enterprises, Technological and Economic Development of Economy 16(3): 432-454. doi:10.3846/tede.2010.27

Roy, B. 1990. Wielokriterialne wspomaganie decyzji [Multiple criteria decision-making support]. Warsaw: WNT.

Roy, B.; Bouyssou, D. 1993. Aide Multicritére á la Décision: Méthodes et Cas. Paris: Economica.

Sacks, R.; Harel, L. M. 2006. An economic game theory model of subcontractor resource allocation behaviour, Construction Management and Economics 24(8): 869-881. doi:10.1080/01446190600631856

Tam, C. M.; Tong, T. K. L.; Lau, C. T. 2003. ELECTRE III in evaluating performance of construction plants: case study on concrete vibrators, Construction Innovation 3(1): 4-61.

Thiel, T. 2006. A proposal of defining participant preferences in a decision aiding process with the participant representing a collective body, Technological and Economic Development of Economy 12(3): 257-262.

Thiel, T. 2008. Determination of the relative importance of criteria when the number of people judging is a small sample, Technological and Economic Development of Economy 14(4): 566-577. doi:10.3846/1392-8619.2008.14.566-577
Thiel, T.; Mroz, T. 2001. Application of multi-criterion decision aid method in designing heating systems for museum buildings, Informatica 12(1): 133-146.

Trzaskalik, T. (Ed.). 2006. Metody wielokryterialne na polskim rynku finansowy [Multiple criteria methods in the Polish financial market]. Warsaw: PWE.

Turskis, Z. 2008. Multi-attribute contractors ranking method by applying ordering of feasible alternatives of solutions in terms of preferability technique, Technological and Economic Development of Economy 14(2): 224-239. doi:10.3846/1392-8619.2008.14.224-239

Ulubeyli, S.; Manisali, E.; Kazaz, A. 2010. Subcontractor selection practices in international construction projects, Journal of Civil Engineering and Management 16(1): 47-56. doi:10.3846/jcem.2010.04

Ulubeyli, S.; Kazaz, A. 2009. A multiple criteria decisionmaking approach to the selection of concrete pumps, Journal of Civil Engineering and Management 15(4): 369-376. doi:10.3846/1392-3730.2009.15.369-376

Ustinovichius, L.; Zavadskas, E. K.; Lunkevichius, S.; Shevchenko, G. 2006. Multiple criteria analysis for assessing the investment projects in rural property revitalization, in International Conference on Operational Research: Simulation and Optimization in Business and InIndustry, May 17-20, Tallinn, Estonia, 194-195.

Wong, P. S. P.; Cheung, S. O.; Ho, P. K. M. 2005. Contractor as trust initiator in construction partnering - prisoner's dilemma perspective, Journal of Construction Engineering and Management 131(10): 1045-1053. doi:10.1061/(ASCE)0733-9364(2005)131:10(1045)

Zavadskas, E. K. 1987a. Complex Evaluation and Selection of Resource-Saving Decisions in Construction. Vilnius: Mokslas.

Zavadskas, E. K. 1987b. The grounds of rational choice of the upper floor construction on taking into account some criteria, Zeszyty Naukowe Politechniki Poznańskiej, Budownictwo Ladowe 30: 141-149 (in Polish).

Zavadskas, E. K.; Turskis, Z.; Tamošaitienė, J. 2008. Contractor selection of construction in a competitive environment, Journal of Business Economics and Management 9(3): 181-187. doi:10.3846/1611-1699.2008.9.181-187

Zavadskas, E. K.; Ustinovichius, L; Stasiulionis, A. A. 2004. Multicriteria evaluation of commercial construction projects for investment processes, Journal of Civil Engineering and Management 10(2): 151-166.

\section{METODAI, LEIDŽIANTYS BENDRADARBIAVIMUI PASIRINKTI GERIAUSIĄ STATYBOS İMONE, ATSIŽVELGIANT İ PARTNERYSTĖS SANTYKIUS}

\section{E. Radziszewska-Zielina}

Santrauka

Siūloma 14 parametrų, kaip statybos įmonėse ịvertinti partnerystės santykius. Remdamiesi šiais parametrais, statybos ịmoniu ekspertai pagal penkiabalę sistemą įvertina įmonès santykius su keturiais jos mikroaplinkoje veikiančiais partneriais. Santykius apibūdinantys parametrai naudojami kaip vertinimo kriterijai. Geriausios statybos įmonès pasirinkimas bendradarbiavimui - daugiakriterinis klausimas. Autorès pateiktas sprendimas pagrịstas ELECTRE III metodu. Ji nagrinèja du alternatyvius metodus, kaip geriausią statybos įmonę pasirinkti išanalizavus partnerystès santykius tarp nagrinėjamų statybos įmonių ir mikroaplinkoje veikiančių jų partnerių. Vienam metodui ji teikè pirmenybę. Abu metodai papildo statybos įmonès sprendimų prièmimo sistemą, kai reikia pasirinkti subrangovą. İmonèje sprendimus priimantis asmuo reikiamus skaičiavimus gali atlikti naudodamasis ConRel programa, parengta Krokuvos technologijos universitete.

Reikšminiai žodžiai: statybos įmonè, partneryste, partnerystès santykiai, subrangovo pasirinkimas, daugiakriterinis metodas, ELECTRE III.

Elżbieta RADZISZEWSKA-ZIELINA. PhD is educated as an construction engineer and a sociologist. Nowadays, she works as Assistant Professor at the Department of Civil Engineering in Cracow University of Technology in Division of Construction Technology and Organization. She is interested in Building Marketing and Management. 